\begin{tabular}{|c|l|}
\hline Title & Phase Separation of Halogen-Containing Sodium Borosilicate Glasses \\
\hline Author(s) & UO, Motohiro; Y A MA SHIKA, Y ujiro; MORITA, Kazuki; KA RUBE, Isao; MA KISHIMA, A kio \\
\hline Citation & Journal of Ceramic Society of Japan, 100, 17-21 \\
\hline Issue Date & 1992-01 \\
\hline Doc URL & http://hdl.handle.net/2115/17006 \\
\hline Type & article \\
\hline File Information & JCSJ100-17.pdf \\
\hline
\end{tabular}

Instructions for use 


\title{
Phase Separation of Halogen-Containing Sodium Borosilicate Glasses
}

\author{
Motohiro UO, Yujiro YAMASHIKA, Kazuki MORITA, Isao KARUBE* and Akio MAKISHIMA
}

Department of Materials Science, Faculty of Engineering, The University of Tokyo, 7-3-1, Hongo, Bunkyo-ku, Tokyo 113

*Research Center for Advanced Science and Technology, The University of Tokyo, 4-6-1, Komaba, Meguro-ku, Tokyo 153

\author{
ハロゲン含有ソーダボロシリケートガラスの分相 \\ 宇尾基弘・山鹿勇次郎・森田一樹 · 軽部征夫*・牧島亮男 \\ 東京大学工学部材料学科, 113 東京都文京区本郷 7-3-1 \\ *東京大学先端科学技術研究センター, 153 東京都目黒区駒場 4-6-1
}

[Received July 12, 1991; Accepted September 19, 1991]

\begin{abstract}
Porous glasses were prepared by phase separation and leaching of $\mathrm{NaF}, \mathrm{NaCl}$ and $\mathrm{NaBr}$ containing sodium borosilicate glasses with low silica content. Each sodium halide was added to $10 \mathrm{Na}_{2} \mathrm{O} \cdot 50 \mathrm{~B}_{2} \mathrm{O}_{3} \cdot 40 \mathrm{SiO}_{2}(\mathrm{wt} \%)$ glass and the effects of the additive on phase separation and leaching were investigated. The mean pore diameter, specific surface area and porosity were 300$2500 \AA, 20-60 \mathrm{~m}^{2} / \mathrm{g}$ and $55-56 \%$, respectively. The pore diameter increased and the specific surface area decreased with increasing temperature, time of heat treatment and halogen content. It was found that the halogen containing specimens were leached out in shorter soaking time than the halogen free specimen and that chlorine addition was most effective. The change in the leaching rate is probably caused by the dissolution of halogen containing sodium borate phase into hot water. For chlorine containing sample, leaching finished in a half time that of the halogen free sample.
\end{abstract}

Key-words : Phase separation, Porous glass, Sodium borosilicate glass, Spinodal decomposition, Halogen content, Leaching, Pore diameter, Surface area

\section{Introduction}

Porous silica glass has been studied for useful application for filters, desalination membrane and catalyst or enzyme carrier because of its micro-structure, chemical and thermal durability. Porous silica glass is usually prepared from sodium borosilicate glass with high silica content (ca. $60 \mathrm{wt} \%$ ) by heat treatment for phase-separation and leaching sodium borate phase with acid solution. Hammel et al. ${ }^{1)}$ have reported the preparation of porous glass which is made of relatively low silica content (about $40 \mathrm{wt} \%$ $\mathrm{SiO}_{2}$ ) sodium borosilicate glass. This porous silica glass has many advantages as follows:

(1) Low melting temperature (about $1200^{\circ}-$ $\left.1300^{\circ} \mathrm{C}\right)$.

(2) Pore volume ranges up to $0.6 \mathrm{~cm}^{3} / \mathrm{g}$, while porous glass prepared from high silica content was up to $0.3 \mathrm{~cm}^{3} / \mathrm{g}$.

(3) High silica content (about 99\%) for porous glass.

(4) Leaching treatment is carried out in hot water.

As carrier of catalyst and enzyme, high pore volume is desired, thus the porous glass from sodium borosilicate glass with low silica content is favorable for this application.

Effect of fluorine addition on phase separation and leaching were reported by Takusagawa et al. ${ }^{2}$ ) They reported the effect of fluorine addition for sodium borosilicate glasses with high silica content, and found that the fluorine promoted phase separation. However, effect of fluorine addition for low silica composition has not been reported.

In this study, the effect of halogen addition on phase separation and leaching was investigated for sodium borosilicate glasses with low silica content.

\section{Experimental procedure}

The composition of original glasses was $40 \mathrm{wt} \%$ of $\mathrm{SiO}_{2}$ and molar ratio of $\mathrm{Na} / \mathrm{B}$ was equal to 0.22 . Without sodium halide, the glass composition was $10 \mathrm{Na}_{2} \mathrm{O} \cdot 50 \mathrm{~B}_{2} \mathrm{O}_{3} \cdot 40 \mathrm{SiO}_{2}($ wt $\%)$. Halogen was added to be 1 or $2 \mathrm{wt} \%$ by using sodium halides $(\mathrm{NaF}$, $\mathrm{NaCl}$ and $\mathrm{NaBr}$ ) as starting chemicals.

The reagent grade chemicals of $\mathrm{Na}_{2} \mathrm{~B}_{4} \mathrm{O}_{7}, \mathrm{~B}_{2} \mathrm{O}_{3}$, $\mathrm{SiO}_{2}$ were mixed and in case of halogen addition, sodium halide was added, and the mixture was melted at $1400^{\circ} \mathrm{C}$ for $1 \mathrm{~h}$ in a platinum crucible under argon flow and melt was poured in a graphite crucible (23 $\mathrm{mm}$ o.d., $20 \mathrm{~mm}$ i.d. and $50 \mathrm{~mm}$ in height). These mother glasses are heated at various temperatures ranging from $500^{\circ}$ to $600^{\circ} \mathrm{C}$ for 24 to $240 \mathrm{~h}$ to promote the phase-separation in glass samples.

The phase-separated samples were cut into disk form ( $20 \mathrm{~mm}$ in diameter and $2 \mathrm{~mm}$ in thickness) and leached in hot water at $95^{\circ} \mathrm{C}$ for $24 \mathrm{~h}$. After leaching, porous glasses were dried at $140^{\circ} \mathrm{C}$ for $2 \mathrm{~h}$ in the air.

For the phase-separated and porous glasses, halogen content was determined with a halogen sensitive electrode. For the porous glasses, measurements of specific surface area, pore size distribution and electron microscopic observation were carried out by mercury porosimetry, gas adsorption and scanning electron microscopy. 


\section{Results}

\subsection{Halogen content of mother glasses}

Compositions of prepared glasses are shown in Table 1. The halogen content of mother glasses and porous glasses were determined with a halogen sensitive electrode. The halogen contents of mother glasses are shown in Table 2 and some evaporation of halogens were observed. In the porous glasses, residual halogen contents were lower than $0.1 \mathrm{wt} \%$. Thus most part of added halogen was included in $\mathrm{Na}_{2} \mathrm{O}-$ $\mathrm{B}_{2} \mathrm{O}_{3}$ phase and it was removed in leaching process.

\subsection{Electron microscopic images of sample} glasses

Halogen free and $\mathrm{F}, \mathrm{Cl}, \mathrm{Br}$ added specimens (composition $1,3,5,6)$ are treated at $580^{\circ} \mathrm{C}$ for $48 \mathrm{~h}$ and electron microscopic observations were carried out. As Figs. 1(b)-(d) show, porous glasses prepared

Table 1. Compositions of halogen containing sodium borosilicate glasses.

\begin{tabular}{ccccl}
\hline Composition & $\mathrm{Na}_{2} \mathrm{O}$ & $\mathrm{B}_{2} \mathrm{O}_{3}$ & $\mathrm{SiO}_{2}$ & $\mathrm{NaX}$ \\
\hline 1 & 10.0 & 50.0 & 40.0 & $\ldots$ \\
2 & 8.6 & 49.7 & 39.8 & $1.9 \mathrm{wt} \% \mathrm{NaF}(2.9 \mathrm{~mol} \%)$ \\
3 & 7.8 & 49.6 & 39.7 & $2.9 \mathrm{wt} \% \mathrm{NaF}(4.3 \mathrm{~mol} \%)$ \\
4 & 9.5 & 49.8 & 39.8 & $0.9 \mathrm{wt} \% \mathrm{NaCl}(1.0 \mathrm{~mol} \%)$ \\
5 & 9.2 & 49.7 & 39.7 & $1.4 \mathrm{wt} \% \mathrm{NaCl}(1.6 \mathrm{~mol} \%)$ \\
6 & 9.4 & 49.4 & 39.5 & $1.7 \mathrm{wt} \% \mathrm{NaBr}(1.1 \mathrm{~mol} \%)$ \\
\hline
\end{tabular}

Table 2. Halogen content of glasses listed in Table 1.

\begin{tabular}{cccc}
\hline Composition & halogen & before melting & after melting \\
\hline 1 & -- & -- & -- \\
2 & $\mathrm{~F}$ & $1.0 \mathrm{wt} \%$ & $0.85 \mathrm{wt} \%$ \\
3 & $\mathrm{~F}$ & $2.0 \mathrm{wt} \%$ & $1.3 \mathrm{wt} \%$ \\
4 & $\mathrm{Cl}$ & $1.0 \mathrm{wt} \%$ & $0.54 \mathrm{wt} \%$ \\
5 & $\mathrm{Cl}$ & $2.0 \mathrm{w} \%$ & $0.88 \mathrm{w} \%$ \\
6 & $\mathrm{Br}$ & $2.0 \mathrm{wt} \%$ & $1.3 \mathrm{wt} \%$ \\
\hline
\end{tabular}

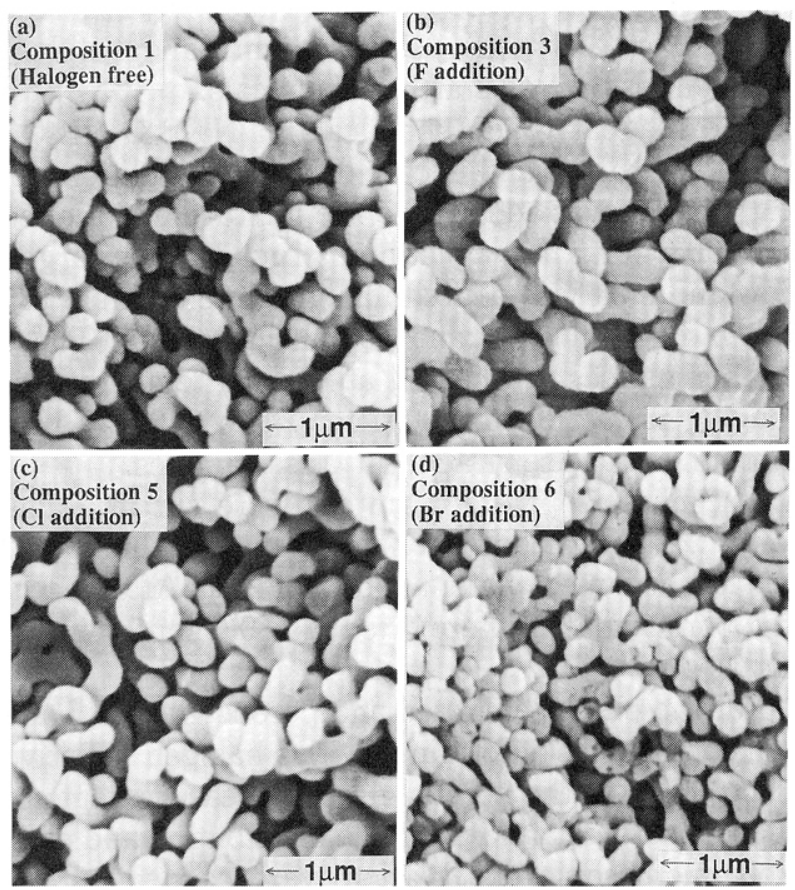

Fig. 1. SEM images of porous glasses prepared from halogen free and $\mathrm{F}, \mathrm{Cl}$ and $\mathrm{Br}$ containing glasses. from halogen containing glasses have the $\mathrm{SiO}_{2}$ interconnecting structures which were probably resulting from spinodal decomposition. Their micro-structures were similar to the porous glass from halogen free glass shown in Fig. 1(a).

3.3 Effect of heat treatment conditions and halogen additions on phase separation

Pore size distributions are shown in Fig. 2 for compositions 3, 5 and 6 . All specimens show sharp pore distribution curves and pore size increased with increasing heat treatment temperature. Mean pore diameter and specific surface area of samples treated at various temperatures for $48 \mathrm{~h}$ are shown in Table 3.

For the fluorine added specimens, the relationship between pore diameter and specific surface area and temperature of heat treatment is shown in Fig. 3 . The heat treatment time is $48 \mathrm{~h}$. The pore diameter increases from about $300 \AA$ to $2500 \AA$ and the specific surface area decreases from $60 \mathrm{~m}^{2} / \mathrm{g}$ to $20 \mathrm{~m}^{2} / \mathrm{g}$ with increasing the treatment temperature from $500^{\circ}$ to $600^{\circ} \mathrm{C}$. Thus the micro-structure of porous glass enlarged with increasing of treatment temperature.

The pore diameter slightly increased with increasing fluorine content. This may show the promotion of phase separation with fluorine addition. The promotion of phase separation by fluorine was reported by Takusagawa et al. ${ }^{2)}$ for $7 \mathrm{Na}_{2} \mathrm{O} \cdot 23 \mathrm{~B}_{2} \mathrm{O}_{3} \cdot 70 \mathrm{SiO}_{2}$ (wt\%) glass. Same effect was observed for this glass system. Same tendency was observed for chlorine containing samples as shown in Table 3 , however the bromine addition was not so effective on pore diameter change.

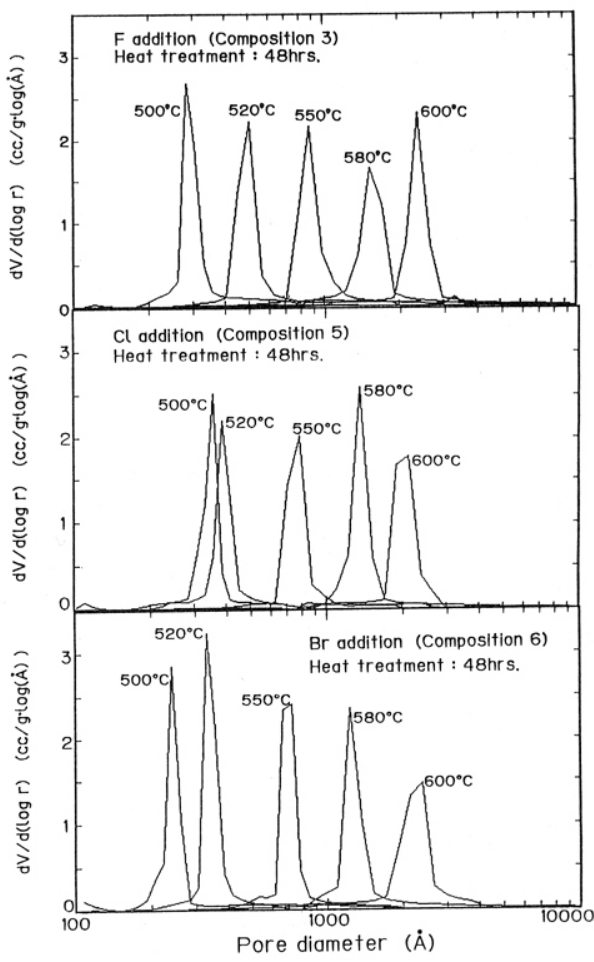

Fig. 2. Pore size distribution curves of porous glasses. 
Table 3. Mean pore diameter and specific surface area of porous glasses treated at various temperatures.

\begin{tabular}{|c|c|c|c|}
\hline $\begin{array}{l}\text { Composition of } \\
\text { mother glass }\end{array}$ & $\begin{array}{l}\text { Condition of } \\
\text { heat treatment }\end{array}$ & $\begin{array}{l}\text { mean pore } \\
\text { diameter }(\AA)\end{array}$ & $\begin{array}{l}\text { specific surface } \\
\text { area }\left(\mathrm{m}^{2} / \mathrm{g}\right)\end{array}$ \\
\hline 1 & $\begin{array}{l}500^{\circ} \mathrm{C} \times 48 \mathrm{hrs} \\
520^{\circ} \mathrm{C} \times 48 \mathrm{hrs} \\
550^{\circ} \mathrm{C} \times 48 \mathrm{hrs} \\
580^{\circ} \mathrm{C} \times 48 \mathrm{hrs} \\
600^{\circ} \mathrm{C} \times 48 \mathrm{hrs}\end{array}$ & $\begin{array}{r}260 \\
358 \\
800 \\
1320 \\
2634\end{array}$ & $\begin{array}{l}32.6 \\
29.1\end{array}$ \\
\hline 2 & $\begin{array}{l}500^{\circ} \mathrm{C} \times 48 \mathrm{hrs} \\
520^{\circ} \mathrm{C} \times 48 \mathrm{hrs} \\
550^{\circ} \mathrm{C} \times 48 \mathrm{hrs} \\
580^{\circ} \mathrm{C} \times 48 \mathrm{hrs} \\
600^{\circ} \mathrm{C} \times 48 \mathrm{hrs}\end{array}$ & $\begin{array}{r}294 \\
462 \\
846 \\
1562 \\
2150\end{array}$ & $\begin{array}{l}70.4 \\
60.6 \\
36.8 \\
23.9 \\
20.7\end{array}$ \\
\hline 3 & $\begin{array}{l}500^{\circ} \mathrm{C} \times 48 \mathrm{hrs} \\
520^{\circ} \mathrm{C} \times 48 \mathrm{hrs} \\
550^{\circ} \mathrm{C} \times 48 \mathrm{hrs} \\
580^{\circ} \mathrm{C} \times 48 \mathrm{hrs} \\
600^{\circ} \mathrm{C} \times 48 \mathrm{hrs}\end{array}$ & $\begin{array}{r}352 \\
560 \\
988 \\
1574 \\
2388\end{array}$ & $\begin{array}{l}68.7 \\
52.8 \\
32.4 \\
20.6 \\
17.9\end{array}$ \\
\hline 4 & $\begin{array}{l}500^{\circ} \mathrm{C} \times 48 \mathrm{hrs} \\
520^{\circ} \mathrm{C} \times 48 \mathrm{hrs} \\
550^{\circ} \mathrm{C} \times 48 \mathrm{hrs} \\
580^{\circ} \mathrm{C} \times 48 \mathrm{hrs} \\
600^{\circ} \mathrm{C} \times 48 \mathrm{hrs}\end{array}$ & $\begin{array}{r}246 \\
420 \\
794 \\
1400 \\
2102\end{array}$ & \\
\hline 5 & $\begin{array}{l}500^{\circ} \mathrm{C} \times 48 \mathrm{hrs} \\
520^{\circ} \mathrm{C} \times 48 \mathrm{hrs} \\
550^{\circ} \mathrm{C} \times 48 \mathrm{hrs} \\
580^{\circ} \mathrm{C} \times 48 \mathrm{hrs} \\
600^{\circ} \mathrm{C} \times 48 \mathrm{hrs}\end{array}$ & $\begin{array}{r}382 \\
562 \\
800 \\
1464 \\
1994\end{array}$ & \\
\hline 6 & $\begin{array}{l}500^{\circ} \mathrm{C} \times 48 \mathrm{hrs} \\
520^{\circ} \mathrm{C} \times 48 \mathrm{hrs} \\
550^{\circ} \mathrm{C} \times 48 \mathrm{hrs} \\
580^{\circ} \mathrm{C} \times 48 \mathrm{hrs} \\
600^{\circ} \mathrm{C} \times 48 \mathrm{hrs}\end{array}$ & $\begin{array}{r}292 \\
366 \\
714 \\
1162 \\
2064\end{array}$ & \\
\hline
\end{tabular}

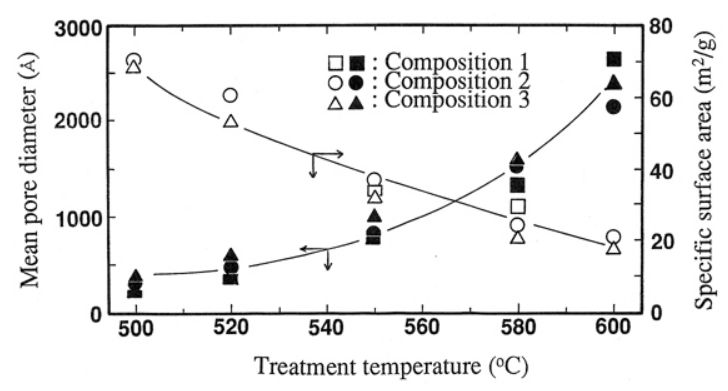

Fig. 3. Relationship between pore diameter, specific surface area and heat treatment temperature.

For the fluorine added specimens, the dependence of pore diameter and specific surface area on heat treatment time is shown in Fig. 4. The heat treatment temperature is $550^{\circ} \mathrm{C}$. The pore diameter increases from about $600 \AA$ to $1200 \AA$ and the specific surface area decreases from $50 \mathrm{~m}^{2} / \mathrm{g}$ to $30 \mathrm{~m}^{2} / \mathrm{g}$ with increasing the treatment time from $24 \mathrm{~h}$ to $120 \mathrm{~h}$. Thus the micro-structure of porous glass enlarged with increasing of treatment time.

\subsection{Weight changes in hot water leaching}

Behavior in leaching of phase separated glass was observed for same samples shown in Figs. 1(a)-(d). Weight changes in hot water leaching are shown in Fig. 5. Samples were treated at $580^{\circ} \mathrm{C}$ for $48 \mathrm{~h}$ and cut into disk form and leached in hot water $\left(95^{\circ} \mathrm{C}\right)$

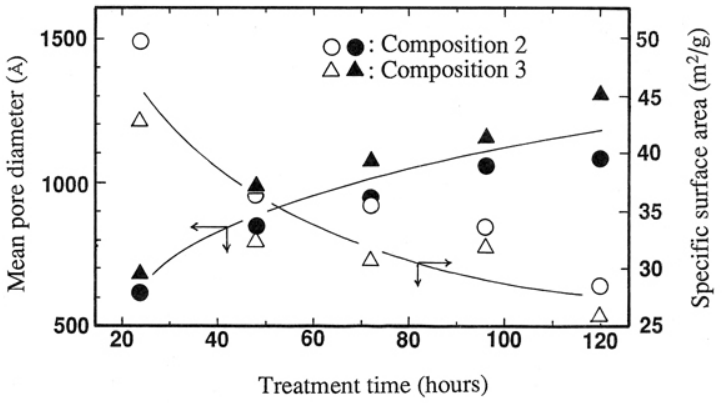

Fig. 4. Relationship between pore diameter, specific surface area and heat treatment time.

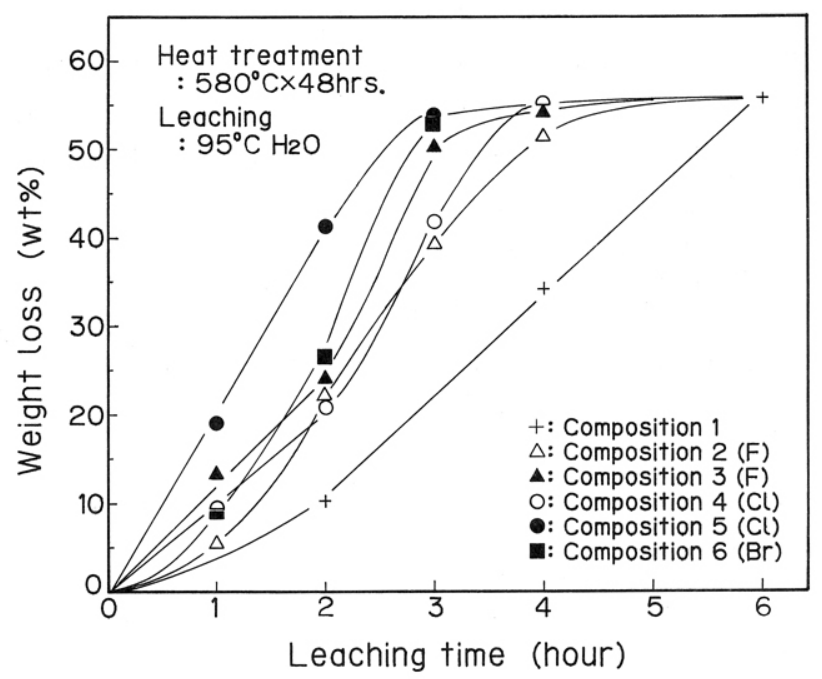

Fig. 5. Weight loss in leaching treatment.

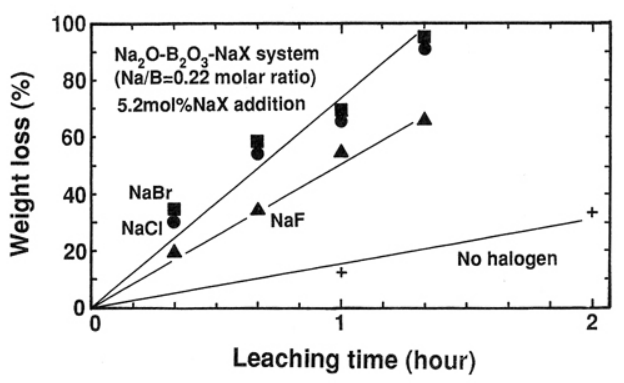

Fig. 6. Weight loss of $\mathrm{Na}_{2} \mathrm{O}-\mathrm{B}_{2} \mathrm{O}_{3}-\mathrm{NaX}(\mathrm{X}: \mathrm{F}, \mathrm{Cl}, \mathrm{Br})$ in water at $95^{\circ} \mathrm{C}$.

for 1 to $6 \mathrm{~h}$. The halogen containing glass was leached out in shorter soaking time than halogen free glass and leaching rate was increased with increasing halogen content. For chlorine containing sample (Composition 5), the leaching finished in a half time of halogen free sample (Composition 1).

Change in dissolving rates in $17 \mathrm{Na}_{2} \mathrm{O} \cdot 83 \mathrm{~B}_{2} \mathrm{O}_{3}$ (wt\%) glasses with halogen addition was observed as Fig. 6. This sodium borate glass composition is considered as the soluble phase of phase separated glass and $5.2 \mathrm{~mol} \%$ of sodium halides were added. The dissolving rate of sodium borate glass increased 
by the addition of halogen and the dissolving rate of chlorine and bromine containing samples were higher than fluorine containing sample.

\section{Discussion}

The relationship between the surface area and treatment time was studied by Haller ${ }^{3)}$ and different relations were presented for each transport mode in microphase rearrangement process of phase separated glasses as Table 4 . For sodium borosilicate glass with $68 \mathrm{wt} \%$ of $\mathrm{SiO}_{2}$ content, $t^{-1 / 2}$ proportionality was also reported by Haller ${ }^{3)}$ as Eq. (1).

$$
A=K \cdot t^{-1 / 2}
$$

where $A:$ specific surface area, $t:$ treatment time

$$
K: \text { constant }
$$

The shape of micro pore is usually described by cylindrical model. In this case, the relationship between pore radius ' $r$ ' and surface area ' $A$ ' is described as Eq. (2).

$$
A=2 \mathrm{~V} / \mathrm{r}
$$

where $V$ : pore volume

Thus, surface area would be in proportion to reciprocal of pore radius and Eq. (3) is derived from Eqs. (1) and (2).

\begin{tabular}{|c|c|}
\hline Transport mode & $\begin{array}{l}\text { Decrease of } \\
\text { surface area }\end{array}$ \\
\hline $\begin{array}{l}\text { Volume diffusion: } \\
\text { (Case 1) } \\
\text { Fast diffusion across small distances } \\
\text { Process at interfaces is } \\
\quad \text { rate-controlling step }\end{array}$ & $A \propto t^{-1 / 2}$ \\
\hline $\begin{array}{l}\text { (Case 2) } \\
\text { Rapid mass transfer across interface } \\
\text { Slow diffusion across large distances } \\
\quad \text { is rate-controlling step }\end{array}$ & $A \propto t^{-1 / 3}$ \\
\hline $\begin{array}{l}\text { Surface diffusion: } \\
\text { (Case 3) } \\
\text { Fast diffusion across small distances } \\
\text { Vacancy formation is controlling }\end{array}$ & $A \propto t^{-1 / 3}$ \\
\hline $\begin{array}{l}\text { (Case 4) } \\
\text { Rapid vacancy formation } \\
\text { Slow diffusion across large distance } \\
\quad \text { is controlling }\end{array}$ & $A \propto t^{-1 / 4}$ \\
\hline
\end{tabular}

Table 4. Time dependence of surface area for different theoretical growth models.

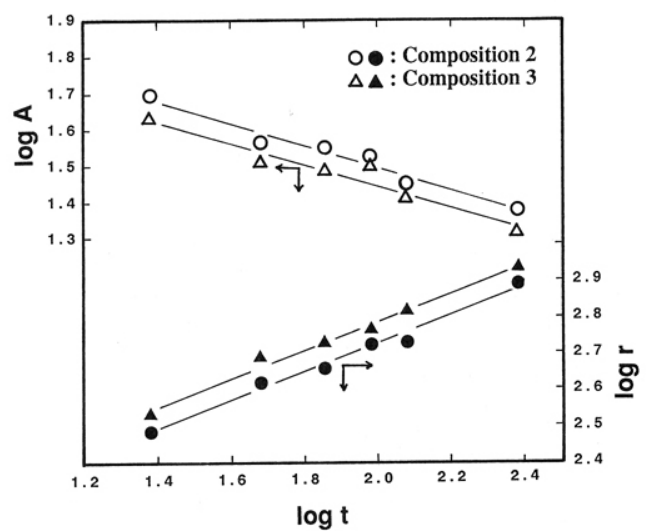

Fig. 7. Dependence of pore radius ' $r$ ' and specific surface area ' $A$ ' on treatment time ' $t$ '.

$$
r=2 V \cdot t^{1 / 2} / K
$$

Nakashima et al. ${ }^{4)}$ reported the $t^{1 / 2}$ proportionality of pore radius as Eq. (3) for $\mathrm{Na}_{2} \mathrm{O}-\mathrm{B}_{2} \mathrm{O}_{3}-\mathrm{SiO}_{2}-\mathrm{Al}_{2} \mathrm{O}_{3}-$ $\mathrm{CaO}$ glass with $63 \mathrm{wt} \%$ of $\mathrm{SiO}_{2}$ content and this relation is agreed with that of Haller. ${ }^{3)}$ Morimoto $^{5}$ reported $t^{1 / 3}$ relation of pore diameter for $\mathrm{SiO}_{2}-\mathrm{B}_{2} \mathrm{O}_{3}$ $\mathrm{Al}_{2} \mathrm{O}_{3}-\mathrm{ZrO}_{2}-\mathrm{RO}-\mathrm{Na}_{2} \mathrm{O}$ glasses with $56-66 \mathrm{wt} \%$ of $\mathrm{SiO}_{2}$ content. Morimoto concluded that phase separation of $\mathrm{SiO}_{2}-\mathrm{B}_{2} \mathrm{O}_{3}-\mathrm{Al}_{2} \mathrm{O}_{3}-\mathrm{ZrO}_{2}-\mathrm{RO}-\mathrm{Na}_{2} \mathrm{O}$ glass took placed by the nucleation growth mechanism resulting in the different time dependence of pore diameter. For the present glass composition (low silica content), the dependence of pore radius and specific surface area on treatment time were plotted in Fig. 7 and it was shown that specific surface area is in proportion to $t^{-0.3}$ and pore radius is to $t^{0.4}$. The $t^{-0.3}$ dependence of surface area corresponds to the case 2 or case 3 in Table 4. Micro-structure of the present glass is larger than that of sodium borosilicate glass with high silica content as studied by Haller. Thus, the rearrangements of micro phase would proceed by the way of bulk diffusion for large distance. If cylindrical model of micro-pore is adequate for the present glass, decrease of surface area and increase of pore diameter should show same time dependence, however different dependency was observed as Fig. 7 for the present study. The reasons for this discrepancy is unknown at present but one of the reasons is that the cylindrical model would not be suitable to interpret the rearrangement of the spherical structure as observed in Figs. 1(a)-(d).

Pore diameters of halogen free and $\mathrm{F}, \mathrm{Cl}, \mathrm{Br}$ containing samples shown in Fig. 5 were $1320 \AA, 1562 \AA$, $1400 \AA$ and $1162 \AA$, respectively, and their differences are relatively small in comparison with the leaching rate. Change in dissolving rate of $\mathrm{Na}_{2} \mathrm{O}$ $\mathrm{B}_{2} \mathrm{O}_{3}$ glass with halogen addition in Fig. 6 shows the same tendency as leaching rate in Fig. 5. Thus, the shortening of the leaching time with halogen addition would be mainly ascribed to differences in dissolving rate of sodium borate phases. One of the authors ${ }^{6)}$ reported that the addition of $\mathrm{P}_{2} \mathrm{O}_{5}, \mathrm{WO}_{3}$ and $\mathrm{V}_{2} \mathrm{O}_{5}$ to the present mother glass is effective to increase the leaching rate. Takusagawa et al.4) reported the promotion of leaching rate by fluorine addition to sodium borosilicate glasses with high silica content. In the present study, the same effect was observed for other halogen containing glasses and for the mother glass of low silica content.

\section{Conclusion}

The porous glasses were prepared from halogen containing sodium borosilicate glass and sharp pore size distribution curves were observed for all samples. The pore diameter increased and the specific surface area decreased with increasing heat treatment temperature, heat treatment time and halogen content. The dependence of pore radius and specific surface area on treatment time were different from 
that of sodium borosilicate glass with high silica content. For the present glass composition, specific surface area is in proportion to $t^{-0.3}$ and pore radius is to $t^{0.4}$. The halogen containing specimen was leached out in shorter soaking time than halogen free specimen and chlorine addition was most effective. The change of the leaching rate would be mainly ascribed to dissolving rate of halogen containing sodium borate phase into hot water.

Acknowledgements The authors would like to acknowledge Dr. H. Inoue of The University of Tokyo for much helpful advice in the preparation on this manuscript. In addition the authors thank to Mr. K. Kotani of National Institute for Research in Inorganic Materials for pore size measurements.

\section{References}

1) J. J. Hammel and T. Allersma, US Pat., 3,843,341 (1974).

2) N. Takusagawa, K. Yamamoto and K. Kitajima, J. Non-Cryst. Solids, 95-96, 1055-62 (1987).

3) W. Haller, J. Chem. Phys., 42, 686-93 (1965).

4) T. Nakashima and Y. Kuroki, Nippon Kagaku Kaishi, 8, 1231-38 (1981).

5) S. Morimoto, Seramikkusu Ronbunshi, 98, 1093-96 (1990).

6) A. Makishima and J. D. Mackenzie, J. Non-Cryst. Solids, 31, 377-83 (1979) 